\title{
The Return of the Monday Effect in European Currency Markets: An Empirical Analysis of the Impact of the Economic Crisis on Market Efficiency.
}

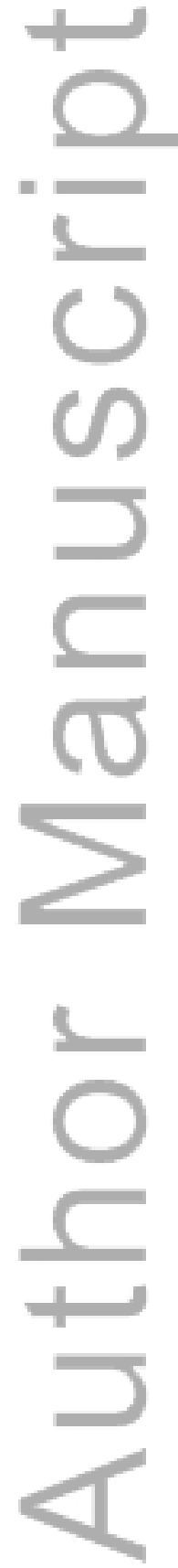

August 9, 2015

This is the author manuscript accepted for publication and has undergone full peer review but has not been through the copyediting, typesetting, pagination and proofreading process, which may lead to differences between this version and the Version of Record. Please cite this article as doi: 10.1002/ijfe.1534

This article is protected by copyright. All rights reserved. 


\begin{abstract}
This paper examines the relationship of multiple currencies, coupled with the Euro, to examine if there is evidence of the return of the Monday effect as a result of the recent global economic crisis. Each currency pair, which consists of the U.S. dollar, Japanese Yen, Great British Pound, Canadian dollar, and Australian dollar, is compared to the Euro to find evidence to support the presence of the Monday effect. The currency pairs are tested in 1999 - 2004 as the first time period, again in 2005 - 2009 as the second time period, and then finally in 2010 - 2012 as the final time period, which represents the period impacted by the economic crisis. It is the authors’ contention that the economic crisis that occurred after 2008 had a significant impact in the currency markets and that the Monday effect has become more pronounced due to a weakening of market efficiency
\end{abstract}

The results provide evidence that in the 2010 - 2012 period three currency pairs exhibit a statistically significant Monday effect. This Monday effect was not evident in either the 1999 2004 or the $2005-2009$ periods, according to our analysis. This leads the authors' to postulate that the economic crisis resulting from the mortgage meltdown has had a statistically verifiable effect on currency markets throughout the world.

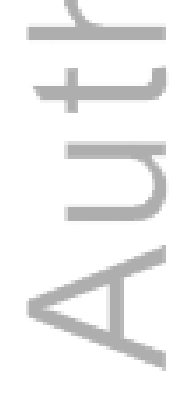




\section{Introduction}

A significant amount of literature has been developed examining the nuances of market efficiency and as a result of these studies, a number of anomalies have been uncovered. This study focuses on one such potential market anomaly, the Monday effect, and attempts to verify its existence in multiple Euro-based currency pairs over the entire period of existence of the Euro currency from 1999 through 2012. The attempt to verify the existence of the Monday effect is of great interest and importance because its existence is precluded by one of the most fundamental propositions in finance - the Efficient Market Hypothesis (EMH).

The following paper will examine the existence of the Monday effect in the relationship of the U.S. dollar, Australian dollar, Canadian dollar, Japanese Yen, and Great British Pound, against the Euro. The time periods to be examined are from 1999 - 2004, 2005 - 2009 and 2010 - 2012. The three time periods were chosen due to the disappearance of the Monday effect in the first part of the $21^{\text {st }}$ century, which has been proven in multiple studies, in order to test for the potential reappearance of the effect after the financial crisis that began in 2008. The Euro is used as the common currency because of its wide spread use as a currency for foreign transactions and its relative efficiency in the market for currency trading.

A brief history of the Euro reveals that the currency was created as a result of the development of the European Union and the treaty that was signed in 1992, which is now known as the Maastricht Treaty. Although the currency was created in 1999, it only circulated in banks and government institutions in the early years and did not become a public currency until 2002, 
when it started to be distributed by the 12 member countries to the broader public (European Central Bank).

The remainder of this paper is organized as follows: Section II provides a brief overview of prior studies related to the Monday effect, Section III details the data set and methodology utilized in this study, Section IV reports the empirical results, and finally Section V concludes the paper.

\section{Literature Review}

The Monday effect has been studied extensively since the 1970's, with many of the past studies focused on equity markets. Cross (1973), French (1980), and Gibbons and Hess (1981) all studied and documented this effect in equity markets with each of the studies providing evidence to support lower market returns on Mondays than on the other days of the week. In connection to these studies there have been other studies performed to examine if the effect occurs in other markets, such as the foreign exchange market. Yu, Chiou, and Jordan-Wagner (2008) studied the effect in the Yen, British Pound, and U.S. dollar and did not provide evidence to support a noticeable Monday effect in the studied period. They did however find that Tuesdays seem to exhibit the largest increase in exchange rates for the week. The period of analysis, which dates 1994 - 2003, coincides with a relatively healthy economy, which may explain the lack of a Monday downturn in the currency markets. 
In contrast, Arsad and Coutts (1996) discovered a statistically significant Monday effect when there was bad news in the stock market based on the Financial Times Industrial Ordinary Shares Index out of the London International Stock Exchange. The study covered an extended period from 1935-1994, which was broken into twelve equal periods over the sixty year study. The authors observed that the downturn on Mondays was significant when there was negative market news present, which was defined by an overall downturn in the stock market and inconsistent when there was good news, defined by an overall upturn in the stock market. Patell and Wolfson (1982) and Penman (1987) also lend validity to the bad news argument and conclude that good news tends to occur during trading hours while bad news tends to occur after hours and on weekends, leading to more downturns on Mondays.

In contrast to Monday effect evidence supported in equity markets, Thatcher and Blenman (2001) studied the dollar/Sterling market and found a drop in exchange rates on Wednesdays. Their work is supported by earlier studies conducted by Goodhart and Figlioli (1991), and Lyons (1995) which also report time-of-the-day effect in intra-day trading. Levi (1978), Bossaerts and Hillion (1991) and Bessembinder (1992) all find a day-of-the-week effect in various currency markets. Some of the reasons cited in these studies attribute the effects to asymmetries in bid-ask spreads, measurement errors, and new information arrival, to name a few. Nôn study to date has been able to definitively define the reason for the day-of-the-weekeffect and such it is plausible that all of the proposed explanations contribute in part to the effect. 
McFarland, Pettit, and Sung (1982) conducted a study on eleven foreign currency pairs and found that dollar denominated price changes are high on Mondays and Wednesdays and low on Thursdays and Fridays for all eleven currencies being traded.

Does the Day-of-the-Week Effect Stay Constant

" 'Connolly (1989) found that the day-of-the-week effect tends to be inconsistent over time. The research provides evidence that the effect is measurable in one period and then is no longer evident in another. The effect also has the tendency to reverse itself at times, where it becomes negative on Friday and positive on Monday, which was highlighted in the Brusa, Liu and Schulman study (2000). Kamara (1997) found that the effect seems to have diminished with the introduction of the S\&P 500 futures contract.

Chang, Pinegar, and Ravichandran (1993) studied whether the effect was consistent over a period of time in international markets. They evaluated 22 stock indices of various markets around the world to test their theory, which was that while the effect exists in some foreign markets it had largely disappeared in U.S. equity markets. Their study covered the period from 1986 to 1992 and the results are consistent with earlier findings by Conolly (1989), where the day-of-the-week effect is statistically non-existent in the U.S. for this time period. In the Jaffe and Westerfield (1985) study, the findings of the Conolly analysis were taken a step further in order to determine if there was a statistically significant effect between the U.S. equity markets and select foreign markets in Australia, Canada, Japan, and the United Kingdom. The study confirmed the Conolly findings for the U.S., but found that there is a Monday effect evident in 
foreign markets which appear to be independent of U.S. equity markets. The Chang, Pinegar, and Ravichandran (1993) study expanded upon the Jaffe and Westerfield study, with the conclusion that there is statistically significant evidence found to support the day-of-the-week effect in select foreign countries.

The purpose of this paper is to determine if there is a Monday effect in foreign currency markets over multiple periods of time and if so, if there is statistical significance to these findings. We will employ the same statistical procedures developed by Connolly (1989) as the basis for this analysis in order to evaluate our theory.

\section{Data and Methodology}

In this paper we will evaluate five different currency pairs where the Euro is used as the base currency and compared to the U.S. dollar, Japanese Yen, Great Brittan Pound, Canadian dollar, and Australian dollar. We have divided the time periods into 3 sub-sections: 1999 - 2004 which serves as a baseline period for the Euro, 2005 - 2009 which serves as the period that represents relative Euro stability, and 2010 - 2012 as a post economic crisis period. We believe that the post economic crisis period will show a statistically significant day-of-the-week effect due to the bad news environment that was created by the financial crisis that began in 2008 .

The daily returns of the currency pairs are calculated based on the function: 


$$
\mathrm{R}_{\mathrm{it}}=\left(\left(\mathrm{I}_{\mathrm{it}}-\mathrm{I}_{\mathrm{it}-1}\right) / \mathrm{I}_{\mathrm{it}-1}\right) * 100
$$

where $R_{i t}$ is the daily percentage return of the currency pair $i$ on day $t, I_{i t}$ and $I_{i t-1}$ are closing values of the currency pair i on days t and t-1 respectively.

Each currency pair is tested for the presence of the Monday effect using the following regression equation:

$R_{t}=\sum_{j=1}^{5} \beta_{j t} D_{j t}+\varepsilon_{t}=\beta_{1} D_{1 t}+\beta_{2} D_{2 t}+\beta_{3} D_{3 t}+\beta_{4} D_{4 t}+\beta_{5} D_{5 t}+\varepsilon_{t}$

where $R_{t}$ is the daily return of the index, $D_{1 t}, D_{2 t}, D_{3 t}, D_{4 t}, D_{5 t}$ are dummy variables for Monday to Friday (that is if $\mathrm{t}$ is a Monday $\mathrm{D}_{1 \mathrm{t}}=1$ otherwise zero etc). The estimated coefficient $\beta_{1}$ will be significantly negative for the currency pairs that exhibit a traditional Monday effect. The $\varepsilon_{\mathrm{t}}$ is the random error term.

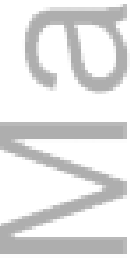

\section{Empirical Results}

Equation (2) is estimated for each currency pair using Ordinary Least Squares, or standard regression analysis, with five dummy variables and no constant term. This regression provides average returns and $t$-statistics for each day-of-the-week that can be used for various levels of comparison.

The results of this analysis are presented in Table 1 , which contains the estimated coefficients and corresponding statistics from the estimation using the data from the 1999 to 
2004 sub-period. As shown, the only average Monday return during this period that is negative and statistically significant at the $10 \%$ level is the EUR/CAD. The EUR/CAD has a negative average Monday return during this period with a statistically significant t-statistic of -1.79129 . The remainder of the day-of-the-week returns provide only one other statistically significant result, which is a positive Friday return for the EUR/JPY currency pair.

The results provided in Table 2 contain the estimated coefficients and corresponding statistics from the estimation using the data from the 2005 to 2009 sub-period. This sub-period does not provide any results that are statistically significant, either negative or positive, except for the Monday return of the EUR/GBP where the return is positive and the t-statistic is statistically significant at 2.00612. In total there are fifty average returns provided in Tables 1 and 2 covering five currency pairs over a ten year period from 1999-2009. Out of the fifty average returns that are calculated, only three of them are significant at the $10 \%$ level and of those, only one of them is negative, statistically significant, and a Monday.

The results provided in Table 3 contain the estimated coefficients and corresponding statistics from the estimation using data from the 2010 to 2012 sub-period. In this period it is noted that there are three currency pairs (out of five) with Monday returns that are both negative and statistically significant, providing evidence of the Monday effect. The EUR/JPY has a negative average Monday return during this period with a statistically significant t-statistic of 1.75036. In addition, the EUR/GBP has a negative average Monday return during this period with a statistically significant t-statistic of -2.12269 . Finally, the EUR/AUD has a negative average Monday return during this period with a statistically significant t-statistic of -2.24570 . 
The Monday average returns generated in this final sub-period provide statistical indication that there is evidence of the Monday effect that is present in multiple Euro currency pairs.

\section{Summary and Conclusions}

The Monday effect has been observed in many studies as outlined in this paper and seems

to occur when there is economic turmoil present in the global economy. When the economy is in a normal growth pattern the effect seems to diminish or disappear altogether, which suggests market efficiency holds in normal periods. This expected normal period market efficiency status has been validated by our study, which shows little to no Monday effect in either of the 19992004 or the 2005-2009 sub-periods, which coincides with a relatively robust world economy. The third sub-period, from 2010-2012 was chosen to examine the impact of the global economic meltdown in the mortgage markets, which led to an overall global recession.. It was our belief that the Monday effect would reappear as the result of this abnormal economic situation, which was supported by our analysis of the third sub-period from 2010-2012.

Evidence of the Monday effect was uncovered in multiple of the currency pairs studied, suggesting that the economic turmoil in the economy had a wide reaching effect, which includes an impact on market efficiency in currency markets. Due to the ongoing global economic crisis,, it would seem logical to assume the Monday Effect is once again evident in various global currency and equity markets, on we believe future research should be conducted to test for the effect. Based on the evidence provided by this paper and supported by many prior studies, there 
is reason to believe that the global economic crisis has interfered with the market efficiency that is evident in normal periods and this interference will likely continue into the near future.

While studies of market efficiency and specifically the Monday effect are not new, the results in recent years (prior to the economic crisis) had produced consistent results supporting the theory that market efficiency had become stronger over time, potentially driven by the broad acceptance of electronic trading. This prevailing theory had led to a decrease in market efficiency studies as their purpose, both in academic and practical terms was called into question. The results provided in this paper provide evidence that the prevailing theory may not be accurate or at least entirely explain the existence of the Monday effect, as the use of electronic trading has only increased throughout the three studied sub-periods. Our conclusion, based on the analysis in this paper, is that perhaps the underlying driver of market efficiency strength is not the use of electronic trading systems, but rather the state of the underlying global economy.

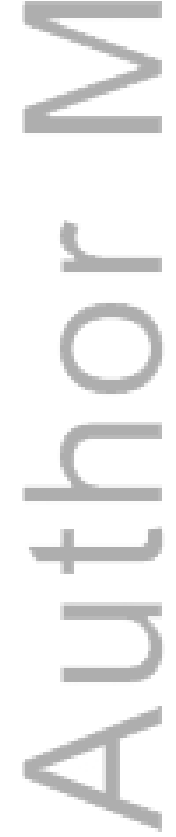




\section{References}

Arsad, Z. and Coutts, J. A. (1996). The Weekend Effect, Good News, Bad News and The Financial Times Industrial Ordinary Shares Index: 1935-1994. Applied Economics

Letters, 3, 797-801.

Bessembinder, H. (1992). Systematic Risk, Hedging Pressure, and Risk Premiums in Futures Markets. Review of Financial Studies 5, 637-667.

Bossaerts, P. and Hillion, P. (1991). Market Microstructure Effects of Government Intervention in the Foreign Exchange Market. Review of Financial Studies, Vol 4, 513-541.

Brusa, J., Liu, P., and Schulman, C. (2000). The Weekend Effect, 'Reverse’ Weekend Effect, and Firm Size. Journal of Business Finance \& Accounting, June/July, 555-574.

Chang, E., Pinegar, J. and Ravichandran, R. (1993). International Evidence on the Robustness of the Day-of-the-Week Effect. Journal of Financial and Quantitative Analysis, 28(4), 497-

\section{3.}

Connolly, R.A. (1989). An Examination of the Robustness of the Weekend Effect. Journal of Financial and Quantitative Analysis, 24(2), 133-169.

Cross, F. (1973). The Behavior of Stock Prices on Fridays and Mondays. Financial Analysis Journal, Nov/Dec, 67-69.

French, K. (1980). Stock Returns and the Weekend Effect. Journal of Financial Economics, Vol. 8, 55-69.

Gibbons, M. and Hess, P. (1981). Day of the Week Effects and Asset Returns. Journal of Business, 54(4), 579-596. 
Goodhart, C. and L. Figlioli. (1991). Every Minute Counts in the Foreign Exchange Markets. Journal of International Money and Finance, Vol 10, 23-52.

Jaffe, J. and Westerfield, R. (1985). The Weekend Effect in Common Stock Returns: The -International Evidence. Journal of Finance, XL (2), 433-454.

Kamara, A. (1997). New Evidence on the Monday Seasonal in Stock Returns. Journal of Business, 70(1), 63-84.

Levi, M. D. (1978). The Weekend Game: Clearing House vs Federal Funds. Journal of Financial Economics, Vol. 39(2-3), 321-351.

Lyons, R. K. (1995). Tests of Microstructural Hypotheses in the Foreign Exchange Market. Journal of Financial Economics, Vol. 39(2-3), 321-351.

McFarland, J., Pettit, R., and Sung, S. (1982). The Disturbance of Foreign Exchange Prices Changes: Trading Day Effects and Risks Measurement. Journal of Finance, June, 693715.

Patell, J. M. and Wolfson, M. A. (1982). Good News, Bad News, and the Intraday Timing of Corporate Disclosures. The Accounting Review, 57(3), 509-527.

Penman, S. (1984). Abnormal Returns to Investment Strategies Based on the Timing of Earnings Reports. Journal of Accounting and Economics, 165-84.

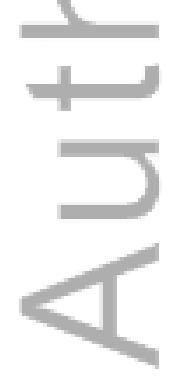


Thatcher, J., and Blenman, L. (2001). Synthetic Trades and Calendar Day Patterns: The Case of the Dollar/Sterling Markets. Financial Review, May, 177-200.

Yu, Hai-Chin, Chiou, Ingyu and Jordan-Wagner, James M. (2008). Does the Weekday Effect of the Yen/Dollar Spot Rates Exist in Tokyo, London, and New York: An Analysis of Panel Probability Distributions. Applied Economics, Vol. 40, 353-375.

$$
=
$$

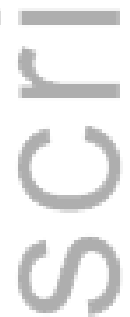

Table 1: Regression Results - EUR Rate Analysis - 5 Currency Pairs (1999 - 2004)

\begin{tabular}{|c|c|c|c|c|c|c|c|}
\hline & & & & & & Adj & Sample \\
\hline Currency Pair & Monday & Tuesday & Wednesday & Thursday & Friday & R-squared & Size \\
\hline \multicolumn{8}{|l|}{3} \\
\hline \multicolumn{8}{|l|}{ EUR/USD } \\
\hline Coefficient & $(0.00023)$ & 0.00008 & 0.00042 & $(0.00024)$ & 0.00055 & $(0.00063)$ & 1536 \\
\hline t-stat & $(0.58619)$ & 0.19690 & 1.09331 & $(0.62617)$ & 1.43554 & & \\
\hline \multicolumn{8}{|l|}{ EUR/JPY } \\
\hline Coefficient & $(0.00069)$ & 0.00046 & $(0.00018)$ & $(0.00045)$ & 0.00115 & 0.00400 & 1536 \\
\hline t-stat & (1.52574) & 1.03704 & $(0.40593)$ & $(1.01440)$ & 2.56461 & & \\
\hline \multicolumn{8}{|l|}{ EUR/GBP } \\
\hline Coefficient & $(0.00026)$ & 0.00041 & 0.00028 & $(0.00040)$ & 0.00001 & 0.00085 & 1536 \\
\hline t-stat & $(0.95359)$ & 1.47651 & 1.03106 & (1.47144) & 0.01839 & & \\
\hline \multicolumn{8}{|l|}{ EUR/CAD } \\
\hline Coefficient & $(0.00073)$ & 0.00030 & 0.00056 & $(0.00045)$ & 0.00014 & 0.00133 & 1536 \\
\hline t-stat & (1.79129) & 0.73271 & 1.38577 & (1.12147) & 0.34960 & & \\
\hline \multicolumn{8}{|l|}{ EUR/AUD } \\
\hline Coefficient & $(0.00039)$ & 0.00007 & 0.00064 & $(0.00016)$ & $(0.00034)$ & $(0.00028)$ & 1536 \\
\hline t-stat & $(0.98248)$ & 0.17512 & 1.63205 & $(0.41382)$ & $(0.85863)$ & & \\
\hline
\end{tabular}

Note: Bold T-statistics indicate statistical significance at the $10 \%$ level or higher

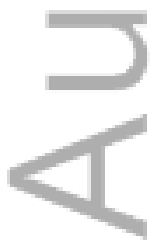

This article is protected by copyright. All rights reserved. 
Table 2: Regression Results - EUR Rate Analysis - 5 Currency Pairs (2005 - 2009)

\begin{tabular}{|c|c|c|c|c|c|c|c|}
\hline & & & & & & Adj & Sample \\
\hline Currency Pair & Monday & Tuesday & Wednesday & Thursday & Friday & R-squared & Size \\
\hline \multicolumn{8}{|l|}{ EUR/USD } \\
\hline Coefficient & $(0.00012)$ & 0.00009 & 0.00034 & 0.00063 & $(0.00061)$ & 0.00032 & 1278 \\
\hline t-stat & $(0.28135)$ & 0.21176 & 0.83615 & 1.55470 & $(1.47255)$ & & \\
\hline \multicolumn{8}{|l|}{ EUR/JPY } \\
\hline Coefficient & 0.00006 & 0.00019 & $(0.00017)$ & 0.00069 & $(0.00078)$ & $(0.00052)$ & 1278 \\
\hline t-stat & 0.11458 & 0.36937 & $(0.33332)$ & 1.34923 & $(1.50364)$ & & \\
\hline \multicolumn{8}{|l|}{ EUR/GBP } \\
\hline Coefficient & 0.00068 & $(0.00029)$ & 0.00046 & 0.00019 & $(0.00008)$ & 0.00154 & 1278 \\
\hline t-stat & 2.00612 & $(0.85568)$ & 1.36080 & 0.56735 & $(0.22293)$ & & \\
\hline \multicolumn{8}{|l|}{ EUR/CAD } \\
\hline Coefficient & $(0.00027)$ & $(0.00017)$ & 0.00010 & 0.00041 & $(0.00025)$ & $(0.00238)$ & 1278 \\
\hline t-stat & $(0.63548)$ & $(0.41373)$ & 0.23166 & 0.98533 & $(0.60825)$ & & \\
\hline \multicolumn{8}{|l|}{ EUR/AUD } \\
\hline Coefficient & $(0.00045)$ & $(0.00038)$ & 0.00400 & $(0.00023)$ & 0.00048 & $(0.00120)$ & 1278 \\
\hline t-stat & $(0.93553)$ & $(0.80026)$ & 0.85494 & $(0.47908)$ & 0.99881 & & \\
\hline
\end{tabular}

Note: Bold T-statistics indicate statistical significance at the $10 \%$ level or higher

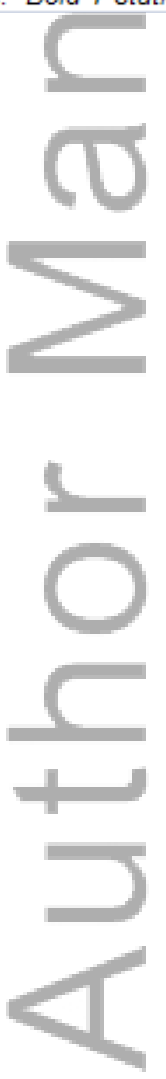


Table 3: Regression Results - EUR Rate Analysis - 5 Currency Pairs (2010 - Current)

\begin{tabular}{|c|c|c|c|c|c|c|c|}
\hline & & & & & & Adj & Sample \\
\hline Currency Pair & Monday & Tuesday & Wednesday & Thursday & Friday & R-squared & Size \\
\hline \multicolumn{8}{|l|}{ EUR/USD } \\
\hline Coefficient & $(0.00067)$ & $(0.00016)$ & 0.00009 & $(0.00050)$ & 0.00059 & $(0.00228)$ & 706 \\
\hline t-stat & (1.17173) & $(0.29419)$ & 0.15916 & $(0.89823)$ & 1.05346 & & \\
\hline \multicolumn{8}{|l|}{ EUR/JPY } \\
\hline Coefficient & $(0.00123)$ & $(0.00112)$ & 0.00110 & $(0.00104)$ & 0.00040 & 0.00821 & 706 \\
\hline$t$-stat & (1.75036) & $(1.61860)$ & 1.60438 & $(1.50725)$ & 0.57678 & & \\
\hline \multicolumn{8}{|l|}{ EUR/GBP } \\
\hline Coefficient & $(0.00091)$ & 0.00014 & $(0.00033)$ & $(0.00055)$ & 0.00093 & 0.00948 & 706 \\
\hline t-stat & (2.12269) & 0.33371 & $(0.78787)$ & (1.31989) & 2.18922 & & \\
\hline \multicolumn{8}{|l|}{ EUR/CAD } \\
\hline Coefficient & $(0.00083)$ & $(0.00010)$ & $(0.00062)$ & $(0.00081)$ & 0.00131 & 0.00953 & 706 \\
\hline t-stat & (1.51612) & $(0.18053)$ & (1.15933) & (1.51372) & 2.41720 & & \\
\hline \multicolumn{8}{|l|}{ EUR/AUD } \\
\hline Coefficient & $(0.00123)$ & 0.00054 & $(0.00070)$ & $(0.00107)$ & 0.00081 & 0.01238 & 706 \\
\hline t-stat & (2.24570) & 0.99034 & (1.29751) & (1.98541) & 1.48943 & & \\
\hline
\end{tabular}

Note: Bold T-statistics indicate statistical significance at the $10 \%$ level or higher 
Table I: Regression Results - Average Daily Returns of Currency Pairs (1999 - 2004)

\begin{tabular}{|c|c|c|c|c|c|c|c|}
\hline Currency Pair & Monday & Tuesday & Wednesday & Thursday & Friday & $\begin{array}{c}\text { Adj } \\
\text { R-squared }\end{array}$ & $\begin{array}{c}\text { Sample } \\
\text { Size }\end{array}$ \\
\hline \multicolumn{8}{|l|}{ EUR/USD } \\
\hline Coefficient & $(0.00023)$ & 0.00008 & 0.00042 & $(0.00024)$ & 0.00055 & $(0.00063)$ & 1536 \\
\hline t-stat & $(0.58619)$ & 0.19690 & 1.09331 & $(0.62617)$ & 1.43554 & & \\
\hline \multicolumn{8}{|l|}{ EUR/JPY } \\
\hline Coefficient & $(0.00069)$ & 0.00046 & $(0.00018)$ & $(0.00045)$ & 0.00115 & 0.00400 & 1536 \\
\hline t-stat & $(1.52574)$ & 1.03704 & $(0.40593)$ & $(1.01440)$ & 2.56461 & & \\
\hline \multicolumn{8}{|c|}{ EUR/GBP } \\
\hline Coefficient & $(0.00026)$ & 0.00041 & 0.00028 & $(0.00040)$ & 0.00001 & 0.00085 & 1536 \\
\hline t-stat & $(0.95359)$ & 1.47651 & 1.03106 & $(1.47144)$ & 0.01839 & & \\
\hline \multicolumn{8}{|l|}{ EUR/CAD } \\
\hline Coefficie & $(0.00073)$ & 0.00030 & 0.00056 & $(0.00045)$ & 0.00014 & 0.00133 & 1536 \\
\hline t-stat & (1.79129) & 0.73271 & 1.38577 & $(1.12147)$ & 0.34960 & & \\
\hline \multicolumn{8}{|l|}{ EUR/AUD } \\
\hline Coefficient & $(0.00039)$ & 0.00007 & 0.00064 & $(0.00016)$ & $(0.00034)$ & $(0.00028)$ & 1536 \\
\hline t-stat & $(0.98248)$ & 0.17512 & 1.63205 & $(0.41382)$ & $(0.85863)$ & & \\
\hline
\end{tabular}

Note: Bold T-statistics indicate statistical significance at the $10 \%$ level or higher

This article is protected by copyright. All rights reserved. 
Table II: Regression Results - Average Daily Returns of Currency Pairs (2005 - 2009)

\begin{tabular}{|c|c|c|c|c|c|c|c|}
\hline Currency Pair & Monday & Tuesday & Wednesday & Thursday & Friday & $\begin{array}{c}\text { Adj } \\
\text { R-squared }\end{array}$ & $\begin{array}{c}\text { Sample } \\
\text { Size } \\
\end{array}$ \\
\hline \multicolumn{8}{|l|}{ EUR/USD } \\
\hline Coefficient & $(0.00012)$ & 0.00009 & 0.00034 & 0.00063 & $(0.00061)$ & 0.00032 & 1278 \\
\hline t-stat & $(0.28135)$ & 0.21176 & 0.83615 & 1.55470 & $(1.47255)$ & & \\
\hline \multicolumn{8}{|l|}{ EUR/JPY } \\
\hline Coefficient & 0.00006 & 0.00019 & $(0.00017)$ & 0.00069 & $(0.00078)$ & $(0.00052)$ & 1278 \\
\hline t-stat & 0.11458 & 0.36937 & $(0.33332)$ & 1.34923 & $(1.50364)$ & & \\
\hline \multicolumn{8}{|c|}{ EUR/GBP } \\
\hline Coefficient & 0.00068 & (0.00029) & 0.00046 & 0.00019 & $(0.00008)$ & 0.00154 & 1278 \\
\hline t-stat & 2.00612 & $(0.85568)$ & 1.36080 & 0.56735 & $(0.22293)$ & & \\
\hline \multicolumn{8}{|l|}{ EUR/CAD } \\
\hline Coefficie & $(0.00027)$ & $(0.00017)$ & 0.00010 & 0.00041 & $(0.00025)$ & $(0.00238)$ & 1278 \\
\hline t-stat & $(0.63548)$ & $(0.41373)$ & 0.23166 & 0.98533 & $(0.60825)$ & & \\
\hline \multicolumn{8}{|l|}{ EUR/AUD } \\
\hline Coefficient & $(0.00045)$ & $(0.00038)$ & 0.00400 & $(0.00023)$ & 0.00048 & $(0.00120)$ & 1278 \\
\hline t-stat & $(0.93553)$ & $(0.80026)$ & 0.85494 & $(0.47908)$ & 0.99881 & & \\
\hline
\end{tabular}

Note: Bold T-statistics indicate statistical significance at the $10 \%$ level or higher

This article is protected by copyright. All rights reserved. 


\begin{tabular}{|c|c|c|c|c|c|c|c|}
\hline Currency Pair & Monday & Tuesday & Wednesday & Thursday & Friday & $\begin{array}{c}\text { Adj } \\
\text { R-squared }\end{array}$ & $\begin{array}{c}\text { Sample } \\
\text { Size }\end{array}$ \\
\hline \multicolumn{8}{|l|}{ EUR/USD } \\
\hline Coefficient & $(0.00067)$ & $(0.00016)$ & 0.00009 & $(0.00050)$ & 0.00059 & $(0.00228)$ & 706 \\
\hline t-stat & (1.17173) & $(0.29419)$ & 0.15916 & $(0.89823)$ & 1.05346 & & \\
\hline \multicolumn{8}{|l|}{ EUR/JPY } \\
\hline Coefficient & $(0.00123)$ & $(0.00112)$ & 0.00110 & $(0.00104)$ & 0.00040 & 0.00821 & 706 \\
\hline t-stat & (1.75036) & (1.61860) & 1.60438 & $(1.50725)$ & 0.57678 & & \\
\hline \multicolumn{8}{|l|}{ EUR/GBP } \\
\hline Coefficient & $(0.00091)$ & 0.00014 & $(0.00033)$ & $(0.00055)$ & 0.00093 & 0.00948 & 706 \\
\hline t-stat & (2.12269) & 0.33371 & $(0.78787)$ & (1.31989) & 2.18922 & & \\
\hline \multicolumn{8}{|l|}{ EUR/CAD } \\
\hline Coefficie & $(0.00083)$ & $(0.00010)$ & $(0.00062)$ & $(0.00081)$ & 0.00131 & 0.00953 & 706 \\
\hline t-stat & $(1.51612)$ & $(0.18053)$ & (1.15933) & $(1.51372)$ & 2.41720 & & \\
\hline \multicolumn{8}{|l|}{ EUR/AUD } \\
\hline Coefficient & $(0.00123)$ & 0.00054 & $(0.00070)$ & $(0.00107)$ & 0.00081 & 0.01238 & 706 \\
\hline t-stat & (2.24570) & 0.99034 & $(1.29751)$ & (1.98541) & 1.48943 & & \\
\hline
\end{tabular}

Note: Bold T-statistics indicate statistical significance at the 10\% level or higher

This article is protected by copyright. All rights reserved. 
The Return of the Monday Effect in European Currency Markets: An Empirical Analysis of the Impact of the Economic Crisis on Market Efficiency.

\author{
Peter J. Bush \\ Lecturer of Finance \\ University of Michigan - Flint \\ Flint, MI 48502 \\ Phone: 810-287-0635 \\ Email: pjbush@umflint.edu \\ John E. Stephens \\ Lecturer of Finance \\ University of Michigan - Flint \\ Flint, MI 48502 \\ Phone: 810-762-0779 \\ Email: johstep@umflint.edu
}

May 29, 2013

This article is protected by copyright. All rights reserved. 